
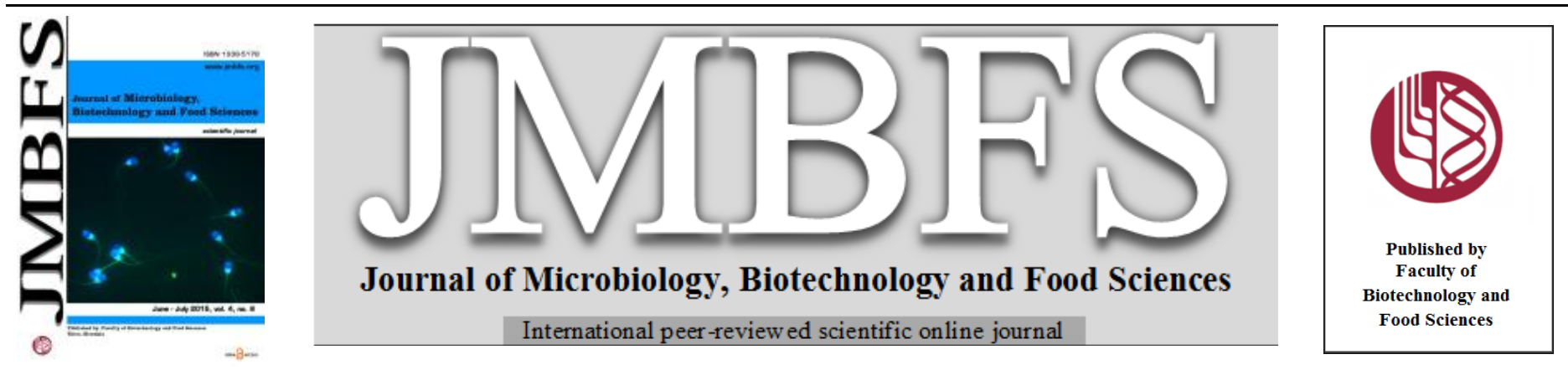

\title{
ANTIBIOTIC RESISTANCE IN LACTIC ACID BACTERIA ISOLATED FROM FERMENTED DAIRY PRODUCTS AND BOZA
}

\author{
Gamze Başbülbül*', Melihcan Özteber ${ }^{1}$, Haci Halil Biyik ${ }^{1}$
}

Address(es): Gamze Başbülbül

Adnan Menderes University, Faculty of Arts and Science, Biology Department, 09010, Aydin/TURKEY. phone number: $00902562182000-1937$

*Corresponding author: gbasbulbul@adu.edu.tr

doi: 10.15414/jmbfs.2015.4.6.513-517

ARTICLE INFO

Received 14. 11. 2014

Revised 9. 3. 2015

Accepted 23. 3. 2015

Published 1. 6. 2015

Regular article

open $\odot$ access

\begin{abstract}
In this study, the resistance of 83 strains of lactic acid bacteria isolated from Turkish cheese, yogurt, kefir and boza samples to 6 antibiotics (gentamicin, tetracycline, chloramphenicol, erythromycin, vancomycin and ciprofloxacin) was evaluated. The 83 isolates were identified by 16S rRNA gene sequencing and according to BLAST comparisons with sequences in the data banks, those strains showing the highest similarities with the isolates were Enterococcus faecium (10), Lactococcus lactis subsp. Lactis (10), Lactobacillus fermentum (6), Lactobacillus plantarum (6), Lactobacillus coryniformis (7), Lactobacillus casei (13), Leuconostoc mesenteroides (14), Pediococcus pentosaceus (10), Weisella confusa (7). Antimicrobial resistance of strains to 6 antibiotics was determined using the agar dilution method. The antibiotic resistance among all the isolates was detected against chloramphenicol (31,3\% of the isolates), tetracycline $(30,1 \%)$, erythromycin $(2,4 \%)$, ciprofloxacin $(2,41 \%)$, vancomycin $(73,5 \%$, intrinsic resistance). Overall $19,3 \%$ of the isolates showed resistance against multiple antibiotics. Antibiotic resistance genes were studied by PCR and the following genes were detected; tet(M) gene in Lactobacillus fermentum (1), Lactobacillus plantarum (1), Pediococcus pentosaceus (5), Enterococcus faecium (2), Weisella confusa (4) and the vancomycin resistance gene van(A) in one Weisella confusa strain.
\end{abstract}

Keywords: Antibiotic resistance, Lactic acid bacteria, Boza, Fermented dairy products

\section{INTRODUCTION}

Lactic acid bacteria (LAB) are a group composed of Gram positive bacteria and they excrete lactic acid into the medium as a main fermentation product (Schleifer \& Ludwig 1995). Many LAB species are present as contaminants on raw agricultural materials or deliberately added as starter cultures into them (Leroy \& de Vuyst, 2004; Capcarova et al., 2011; Sharma et al., 2013). LAB have a long history of safe use as fermenting natural products and probiotics intended for health benefits and have acquired the "Generally recognized as safe" (GRAS) status (Mathur \& Singh, 2005) but there is a great attention to these bacteria may serve as reservoirs of antibiotic resistance (Thumu \& Halami 2012). The main mechanisms of horizontal transfer in bacteria in natural environments are believed to be conjugation and transduction via bacteriophages (Kleinschmidt et al., 1993). LAB have been reported to be capable of supplying antimicrobial resistance genes to food-borne or enteric pathogens (Gevers et al. 2003). According to "qualified presumption of safety" (QPS) concept evolved by European Food Safety Authority (EFSA, 2014), the presence of transmissible antibiotic resistance markers in these bacteria has become an important safety criterion.

Fermented dairy foods and beverages like boza are extensively consumed in Turkey. Therefore investigations on antibiotic resistance profiles of LAB strains common to these products are very important for food safety. In this study antibiotic resistance of LAB strains present in fermented dairy products and boza was tested by phenotypic and genotypic methods, in an attempt to contribute to the knowledge about food associated LAB.

\section{MATERIAL AND METHODS}

\section{Isolation and identification of strains}

Bacterial strains were isolated from fermented dairy products including white cheese, sheep cheese, dry cheese, yogurt, kefir and boza samples from local markets and bazaars in Aydin (Turkey). The samples were initially homogenized and then serial dilutions between $10^{-3}-10^{-6}$ were inoculated to MRS agar (Merck, Darmstadt Germany) plates supplied with $100 \mathrm{mg} / \mathrm{L}$ of cycloheximide ((SigmaAldrich, Taufkirchen, Germany) using spread plate method. MRS agar plates were incubated anaerobically at $30^{\circ} \mathrm{C}$ for 48 hours using the Gas Pack system (Merck, Darmstadt, Germany). Pure cultures of isolates obtained and then strains with gram positive and catalase negative reactions were finally used for further identification.

DNA was extracted from isolates according to phenol-chloroform method defined by Ronimus et al (1997). The following oligonucleotide primers were used to amplify the $16 \mathrm{~S}$ rRNA gene from strains, forward primer $20 \mathrm{~F}$ (5'- AGA GTT TGA TCC TGG CTC AG - 3') and reverse primer 1390R (5'-GAC GGG CGG TGT GTA CAA-3'). PCR was utilized under the following thermocycling conditions: pre-denaturation step at $94{ }^{\circ} \mathrm{C} 5 \mathrm{~min}, 35$ cycles of $94{ }^{\circ} \mathrm{C}$ for $30 \mathrm{~s}, 50$ ${ }^{\circ} \mathrm{C}$ for $30 \mathrm{~s}$ and $72{ }^{\circ} \mathrm{C}$ for $10 \mathrm{~s}$, followed by a final extension step of $72{ }^{\circ} \mathrm{C}$ for 15 min. To determine the closest relatives of the partial 16S rDNA sequences, amplified PCR products sequenced by Macrogene (South Korea). Sequences were BLAST in GenBank database (www.ncbi.nlm.nih.gov) for species assignment.

\section{Antibiotic susceptibility testing}

Minimal Inhibitory Concentrations (MIC) for 6 antibiotics was determined by agar dilution test using multipoint inoculator. Isolates were grown in MRS broth (Merck, Darmstadt, Germany) for 48 hours and then inoculated to LSM Agar $\left(90 \%\right.$ Iso-Sensitest ${ }^{\mathrm{TM}}$ Broth (Oxoid) $+10 \%$ MRS Broth (Merck) $+1,5 \%$ Agar (Merck) (ISO 10932; Klare et al.,2005) plates containing gentamicin, tetracycline, chloramphenicol, erythromycin and vancomycin antibiotics (Oxoid, Hampshire, UK) with the concentration range of $0.0625-128 \mu \mathrm{g} / \mathrm{ml}$ or $0.0625-64$ $\mu \mathrm{g} / \mathrm{ml}$ for ciprofloxacin. The MIC was defined as the lowest concentration of antibiotic giving a complete inhibiton of visible growth in comparison to an antibiotic free control point. Breakpoints were adopted from EFSA report (2008), Ouoba et al., 2008 and Danielsen \& Wind, 2003.

\section{Detection of antibiotic resistance genes in LAB isolates}

PCR amplification of antibiotic resistance genes was done in $50 \mu \mathrm{L}$ volumes that contained 30 pmol of each specific primer (BM Labrotories, Ankara, Turkey), 2 $\mathrm{mM} \mathrm{MgCl}$, $1 \mathrm{X}$ Taq DNA polymerase buffer, each dNTP at a concentration of $200 \mu \mathrm{M}, 1 \mathrm{U}$ of Taq DNA polymerase (ABM, Canada) and $1 \mu \mathrm{L}$ DNA used as a 
template. The oligonucleotide primers and annealing temperatures are listed in Table 1. DNA fragments were amplified in a Techne TC3000 thermocycler up to 40 cycles and PCR products were separated by electrophoresis on 1,2\% agarose jel containing $(0,05 \%, v / v)$ safe view solution. For tet $(M), \operatorname{erm}(C)$ and $\operatorname{van}(A)$ genes positive controls were used.

\begin{tabular}{|c|c|c|c|}
\hline $\begin{array}{l}\text { Resistance } \\
\text { gene }\end{array}$ & Primer & $\mathbf{T}_{\mathrm{a}}{ }^{\circ} \mathbf{C}$ & Reference \\
\hline $\operatorname{tet}(M)$ & $\begin{array}{l}\text { ''-GGTGAACATCATAGACACGC-3' } \\
\text { 5'-CTTGTTCGAGTTCCAATGC-3' }\end{array}$ & $55^{\circ} \mathrm{C}$ & (Werner et al, 2003) \\
\hline $\operatorname{tet}(K)$ & $\begin{array}{l}\text { 5'-CAATACCTACGATATCTA-3' } \\
\text { 5'-TTGAGCTGTCTTGGTTCA-3' }\end{array}$ & $52{ }^{\circ} \mathrm{C}$ & (Werner et al, 2003) \\
\hline $\operatorname{van}(A)$ & $\begin{array}{l}\text { 5'-TTGCTCAGAGGAGCATGACG-3' } \\
\text { 5'-TCGGGAAGTGCAATACCTGC-3' }\end{array}$ & $65^{\circ} \mathrm{C}$ & (Klein et al., 2000) \\
\hline $\operatorname{van}(B)$ & $\begin{array}{l}\text { 5'-TTATCTTCGGCGGTTGCTCG -3', } \\
\text { 5'-GCCAATGTAATCAGGCTGTC-3' }\end{array}$ & $62{ }^{\circ} \mathrm{C}$ & (Klein et al., 2000) \\
\hline cat & $\begin{array}{l}\text { 5'-ATGACTTTTAATATTATTRAWTT-3' } \\
\text { 5'-TCATYTACMYTATSAATTATAT-3' }\end{array}$ & $49^{\circ} \mathrm{C}$ & (Hummel et al., 2007) \\
\hline $\operatorname{erm}(A)$ & $\begin{array}{l}\text { 5'-TCTAAAAAGCATGTAAAAGAA-3', } \\
\text { 5'-CTTCGATAGTTTATTAATATTAGT-3' }\end{array}$ & $52{ }^{\circ} \mathrm{C}$ & (Sutcliffe et al., 1996 \\
\hline $\operatorname{erm}(B)$ & $\begin{array}{l}\text { 5'-GAAAAGGTACTCAACCAAATA-3' } \\
\text { 5'-AGTAACCGTACTTAAATTGTTTAC-3' }\end{array}$ & $52{ }^{\circ} \mathrm{C}$ & (Sutcliffe et al., 1996) \\
\hline $\operatorname{erm}(C)$ & $\begin{array}{l}\text { 5'-TCAAAACATAATATAGATAAA-3' } \\
\text { 5'-GCTAATATTGTTTAAATCGTCAAT-3' }\end{array}$ & $52{ }^{\circ} \mathrm{C}$ & (Sutcliffe et al., 1996) \\
\hline
\end{tabular}

\section{RESULTS}

\section{Identification of bacteria}

Eighty-three presumptive LAB strains isolated from Turkish cheese, yogurt, kefir and boza samples. All isolates were catalase negative and Gram positive rods, cocci or pleomorphics. Strains were identified as Enterococcus faecium (10), Lactococcus lactis subsp. Lactis (10), Lactobacillus fermentum (6), Lactobacillus plantarum (6), Lactobacillus coryniformis (7), Lactobacillus casei (13) Leuconostoc mesenteroides (14), Pediococcus pentosaceus (10), Weisella confusa (7) according to BLAST results.

\section{Phenotypic Profile of Antibiotic Resistance}

Results obtained from the MIC's of tested bacteria are presented in Table 2. None of the tested bacteria were found to be resistant to gentamicin. Only two of the eighty three strains, Enterococcus faecium GL-21 and Weisella confusa GL-33 were resistant to erythromycin. The most prevalent resistances were tetracycline and chloramphenicol $(30,1 \%$ and 31,3 respectively). Twenty five LAB strains including eight of the ten pediococci, two of the ten $E$. faecium and all of the $W$. confusa, displayed phenotypic resistance to tetracycline with MIC values of 8 $\mu \mathrm{g} / \mathrm{ml}$ or higher. For chloramphenicol four of the thirty-two lactobacilli, eight of the ten pediococci, all Weisella strains, two of the ten Enterococci and five of the thirteen Leuc. mesenteroides were found to be resistant with MIC values ranging between 8 and $16 \mu \mathrm{g} / \mathrm{ml}$. Weisella and pediococci seemed like most resistant genera to tetracycline and chloramphenicol. For erythromycin, all LAB isolates displayed MIC values of $2 \mu \mathrm{g} / \mathrm{ml}$ or lower and evaluated as susceptible except for E. faecium GL-21 with MIC value of $32 \mu \mathrm{g} / \mu \mathrm{L}$ and $W$. confusa GL-33 with of $16 \mu \mathrm{g} / \mathrm{ml}$. Lactococcus lactis subsp. Lactis strains isolated in the study did not show any resistance to the tested antibiotics. Obtained LAB strains were intrinsically resistant to vancomycin except for those belonging to genera Enterococcus and Lactococcus which they were found to be susceptible to this antibiotic. E. faecium GLM-160 and E. faecium GLM-161 showed resistance to ciprofloxacin, P.pentosaceus strains were inherent resistant.

\section{Detection of antibiotic resistance genes in LAB isolates}

All of the isolated LAB strains were tested by PCR for the presence of the most frequently detected $\mathrm{AR}$ genes; $\operatorname{tet}(\mathrm{M}), \operatorname{tet}(\mathrm{K}), \operatorname{van}(\mathrm{A}), \operatorname{van}(\mathrm{B}), \operatorname{cat}, \operatorname{erm}(\mathrm{A})$ $\operatorname{erm}(\mathrm{B})$ and $\operatorname{erm}(\mathrm{C})$ regardless of whether or not they are phenotypically resistant to antibiotics. $\operatorname{tet}(\mathrm{M})$ was detected in twelve of the tetracycline resistant LAB strains, while van(A) detected in one of the seven vancomycin resistant Weisella isolates. $\mathrm{Lb}$. fermentum GL-9 and $\mathrm{Lb}$. plantarum which are phenotypically susceptible to tetracycline, were found to carry the tet $(\mathrm{M})$ gene (Table 3).

Table 2 LAB species isolated in the study, numbers and MIC ranges

\begin{tabular}{|c|c|c|c|c|c|c|}
\hline Isolated LAB species & Gentamicin & Tetracycline & Chloramphenicol & Erythromycin & $\begin{array}{c}\text { Vancomyci } \\
\text { n }\end{array}$ & Ciprofloxacin \\
\hline Lb. fermentum $(\mathrm{n}=6)$ & $0.25-8$ & $4-16$ & $2-8$ & $\leq 0,0625-0,25$ & $128-\geq 128$ & $4-16$ \\
\hline Lb. plantarum $(\mathrm{n}=6)$ & $\leq 0,0625-4$ & $2-32$ & $1-8$ & $\leq 0,0625-0,125$ & $\geq 128$ & $1-16$ \\
\hline Lb. coryniformis $(n=7)$ & $1-4$ & $4-32$ & $\leq 0,0625-4$ & $\leq 0,0625-0,5$ & $\begin{array}{l}\leq 0,0625- \\
\quad \geq 128\end{array}$ & $0,5-8$ \\
\hline Lb. casei $(\mathrm{n}=13)$ & $0,25-8$ & $0,125-8$ & $1-16$ & $\leq 0,0625-0,5$ & $\geq 128$ & $0,25-2$ \\
\hline$P$. pentosaceus $(\mathrm{n}=8)$ & $0,5-4$ & $4-32$ & $8-32$ & $\leq 0,0625-0,125$ & $\geq 128$ & $16-32$ \\
\hline P. parvulus $(\mathrm{n}=2)$ & 0,25 & $8-16 r$ & $2-4$ & $\leq 0,0625$ & $\geq 128$ & $1-2$ \\
\hline E. faecium $(\mathrm{n}=10)$ & $8-32$ & $0,125-16$ & $4-16$ & $0,125-32$ & $0,25-1$ & $\leq 0,0625-4$ \\
\hline $\begin{array}{l}\text { L. lactis subsp. lactis } \\
(\mathrm{n}=10)\end{array}$ & $0,25-4$ & $\leq 0,0625-0,5$ & $1-4$ & $\leq 0,0625-0,125$ & $0,125-0,25$ & $0,5-2$ \\
\hline W. confusa $(\mathrm{n}=7)$ & $0,5-8$ & $8-32$ & 16 & $0,125-16$ & $\geq 128$ & $0,25-0,5$ \\
\hline $\begin{array}{l}\text { Leuc. mesenteroides } \\
(\mathrm{n}=14)\end{array}$ & $0,125-2$ & $0.0,5-4$ & $2-4$ & $\leq 0,0625-0,125$ & $\geq 128$ & $0,5-4$ \\
\hline
\end{tabular}


Table 3 PCR positive LAB strains and their MIC values

\begin{tabular}{llc}
\hline LAB strain & Gene & MIC value $(\boldsymbol{\mu g} / \mathbf{m L})$ \\
\hline Lb. fermentum GL-9 & Tet $(\mathrm{M})$ & 8 \\
Lb. plantarum GLM-209 & Tet $(\mathrm{M})$ & 32 \\
P. pentosaceus GL-20 & Tet $(\mathrm{M})$ & 16 \\
P. pentosaceus GL-62 & Tet $(\mathrm{M})$ & 32 \\
P. pentosaceus GL-20 & Tet $(\mathrm{M})$ & 16 \\
$\boldsymbol{P}$. pentosaceus GL-63 & Tet $(\mathrm{M})$ & 32 \\
E. faecium GL-83 & Tet $(\mathrm{M})$ & 16 \\
E. faecium GL-89 & Tet $(\mathrm{M})$ & 16 \\
W.confusa GL-31 & Tet $(\mathrm{M})$ & 8 \\
W.confusa GL-55 & Tet $(\mathrm{M})$ & 8 \\
W.confusa GL-74 & Tet $(\mathrm{M})$ & 8 \\
W.confusa GL-56 & Van $(\mathrm{A})$ & 8128 \\
W.confusa GL-76 & Tet $(\mathrm{M})$ & 8 \\
\hline
\end{tabular}

\section{DISCUSSION}

In the present study, $83 \mathrm{LAB}$ isolates from Turkish fermented foods and boza were isolated and identified by $16 \mathrm{~S}$ rRNA gene sequencing. After bacterial identification, the strains were evaluated by phenotypic and genotypic methods for their antibiotic resistance profiles.

The resistance of the studied Lactobacillus spp. to antibiotics was variable according to species and antibiotic tested. While none of the lactobacilli were resistant to gentamicin, erythromycin or ciprofloxacin, some Lb. fermentum and Lb. coryniformis strains were detected as resistant to tetracyclin and tet $(\mathrm{M})$ gene was found in $L b$. fermentum GL-9 as a silence resistance gene. Chloramphenico resistance was more common in Lb. casei strains (GL-72, GLM-210, GLM-212) than other lactobacilli, only one Lb. fermentum was resistant to chloramphenicol. It has been shown that Lactobacillus spp. are generally susceptible to chloramphenicol, erythromycin and tetracycline (Zhou et al., 2005; RojoBezares et al., 2006; D'Aimo et al., 2007, Bujnakova et al., 2014). However, resistant strains to these agents, and several genes providing resistance have also been identified. For example a chloramphenicol resistance cat gene has been found in Lactobacillus plantarum (Ahn et al., 2002), tet(M) gene in Lactobacillus fermentum isolates (Gfeller et al., 2003). Cataloluk and Gogebakan (2004) reported that six isolates of Lactobacillus casei from dairy products and human origin carried tet $(\mathrm{M})$ genes. A previous study conducted with home-made Spanish cheese reported that L. plantarum, L. acidophilus, $L$. brevis and $L$. casei strains were resistant to tetracycline and chloramphenicol (Herrero et al., 1996)

Lactobacillus spp, P.pentosaceus, W. confusa and L. mesenteroides isolate showed very high MIC values $(128 \mu \mathrm{g} / \mathrm{ml}$ or higher) for vancomycin Leuconostoc, Weissella, Pediococcus, Lactobacillus, and Erysipelothrix are involved in clinically relevant, non-enterococcal intrinsic glycopeptide resistant Gram positive organisms (Klein et al. 2000; Lahtinen et al., 2012). Many strains of Lb. plantarum, Lb. casei, Lb. salivarius, Lb. leichmannii, Lb. acidophilus carry intrinsic resistance towards vancomycin which is due to the presence of Dalanine: D-alanine ligase-related enzymes (Elisha and Courvalin 1995). Intrinsic vancomycin resistance of Lactobacillus, Leuconostoc and Pediococcus species has been used to separate them from other Gram-positive bacteria on vancomycin supplemented selective media (Simpson et al. 1995).

Among the Pediococci isolates, only two were susceptible to tetracycline and tet(M) gene was detected in four resistant Pediococcus pentosaceus strains. As indicated in the literature, data on the antibiotic susceptibility of Pediococcus spp. isolated from food are very scarce (Ammor et al., 2007). Hummel et al. (2007) investigated antibiotic resistances of 45 lactic acid bacteria those belong to the genera Lactobacillus, Streptococcus, Lactococcus, Pediococcus and Leuconostoc. One of the Pediococcus strain P. pentosaceus strain BFE 7436 was found to show low resistance to tetracycline. However, it was reported that neither of the genes those encode the ribosomal protection proteins $[\operatorname{tet}(\mathrm{M})$ tet $(\mathrm{Q}), \operatorname{tet}(\mathrm{S})$ or $\operatorname{tet}(\mathrm{W})]$ nor the genes those encode the tetracycline efflux pumps $[\operatorname{tet}(\mathrm{K})$ or $\operatorname{tet}(\mathrm{L})]$ were found.

While chloramphenicol resistance seems to be common in P. pentosaceus strains isolated in our study, cat gene could not be detected in any of these resistant strains. It has been reported chloramphenicol usually active against Pediococcus pentosaceus isolates [Gevers et al., 2000; Sabir et al., 2010) and susceptibility levels are thought to be species-dependent (Ammor et al., 2007). The ciprofloxacin MICs were $16-32 \mu \mathrm{g} / \mathrm{ml}$ for $P$. pentosaceus. Danielsen et al., (2005) reported that ciprofloxacin resistance in Pediococcus pentosaceus was likely to be an intrinsic property of the species.

Enterococcus faecium strains isolated in our study were found to be resistant to different antibiotics. E. faecium GL-21 showed high level of resistance to erythromycin $(32 \mu \mathrm{g} / \mathrm{ml})$, and also chloramphenicol resistant which was isolated from boza, but none of the $\operatorname{erm}(\mathrm{A}), \operatorname{erm}(\mathrm{B}), \operatorname{erm}(\mathrm{C})$ or cat genes could be detected. Two of the four E. faecium strains, GL-83 and GL-89 were resistant to tetracycline and carried tet $(\mathrm{M})$ gene.
In a study undertaken by Temmerman et al. (2003), a total of 29 E. faecium strains were isolated from different European probiotic products and antibiotic resistance was detected against tetracycline (24\% of the isolates), erythromycin ( $97 \%$ of the isolates) and chloramphenicol (34\% of the isolates). The resistance of Enterococcus species isolated from Turkish white cheese samples to 13 antibiotics is studied by Citak and coworkers (2004) and 96\% of E.faecium isolates were found to be resistant to erythromycin, whereas $76 \%$ and $44 \%$ were resistant to chloramphenicol and tetracycline respectively. Huys and coworkers (2004) have found that $24 \%$ of Enterococcus isolates from European cheeses displayed phenotypic resistance to tetracycline with MIC ranges of 16 to 256 $\mu \mathrm{g} / \mathrm{ml}$. E. faecium GLM-160 and GLM-161 were resistant to ciprofloxacin with MIC values of $4 \mu \mathrm{g} / \mathrm{ml}$. Similarly, ciprofloxacin resistance has been described among E. faecium isolates from different food sources at varying degrees.(Franz et al., 2001; Drahovska et al., 2004; Johnston and Jaykus, 2004; Belicova et al., 2007; Valenzuela et al., 2008)

$W$. confusa is present in some fermented vegetables and milk (Bjorkroth $\boldsymbol{e t}$ al. 2002), as well as in human faeces of healthy individuals (Walter et al., 2001) or in some bacteremia cases (Kumar et al., 2011; Harlan et al., 2011), In Weisella confusa strains from KoKo (fermented millet porridge) of Africa origin, one of these strains was found to be resistant to tetracycline (Ouoba et al., 2008). All the strains belonging to Weisella confusa species in our study showed multiresistant to tetracycline and chloramphenicol. Strain GL-33 which has the highest MIC value for tetracycline was also eryrthromycin resistant.

Ayeni et al., (2011) reported that Weisella confusa isolates obtained from Nigerian dairy products and cow's intestine are chloramphenicol resistant and authors argued that their results could indicate the presence of specific chloramphenicol resistance genes in Weisella.

While the most Leuconostoc species those have been investigated previously were reported to be susceptible to chloramphenicol, like to rifampicin, erythromycin, clindamycin and tetracycline (Swenson et al.; 1990; Florez et al., 2005) Leuc. mesenteroides strains isolated in our study were found to be resistant to chloramphenicol.

\section{CONCLUSION}

Knowledge on the antibiotic resistance of LAB is still limited and it is hard to evaluate the resistance profiles because of the heterogeneity of this group. Our findings suggest that the $\mathrm{LAB}$ strains belonging to the genera Pediococcus, Leuconostoc, Weisella, Enterococcus are generally resistant to clinically relevant antibiotics such as tetracycline and chloramphenicol. The authors concluded that prevalence of antibiotic resistant LAB in traditionally fermented dairy products and boza is high and these kinds of foods should be monitored carefully.

Acknowledgements: This work was supported partially by project granted by Adnan Menderes University Scientific Research Projects ADU-BAP (project no 12032). Dr. Bulent BOZDOĞAN and Dr. Erman ORYAŞIN are thanked for sequencing support., Yasemin SERTEL is also thanked for her technical assistance in the collecting of the samples.

\section{REFERENCES}

AHN C., COLLINS-THOMPSON D., DUNCAN C., STILES M.E. 1992. Mobilization and location of the genetic determinant of chloramphenicol resistance from Lactobacillus plantarum caTC2R. Plasmid 27, 169-176.

AMMOR, M.S., FLÓREZ, A.B., MAYO, B. 2007. Antibiotic resistance in nonenterococcal lactic acid bacteria and bifidobacteria. Food Microbiol 24, 559-70 http://dx.doi.org/10.1016/j.fm.2006.11.001

AYENI, F.A., SÁNCHEZ, B., ADENIYI, B.A., LOS REYES-GAVILÁN, C.G., MARGOLLES, A., MADIEDO, P.R. 2011. Evaluation of the functional potential of Weissella and Lactobacillus isolates obtained from Nigerian traditional fermented foods and cow's intestine. Int J Food Microbiol 147, 97-104 http://dx.doi.org/10.1016/j.ijfoodmicro.2011.03.014

BELICOVÁ, A., KRZKOVÁ, L., KRAJCOVIC, J., JURKOVIC, D., SOJKA, M., EBRINGER, L., DUINSKÝ, R. 2007. Antimicrobial susceptibility of Enterococcus species isolated from Slovak Bryndza cheese. Folia Microbiol 52(2):115-9.

BERGE, A.C.B., ATWILl, E.R., SISCHO, W.M. 2005. Animal and farm influences on the dynamic of antibiotic resistance in faecal Eschrichia coli in young dairy calves. Preventive Veterinary Medicine, 69, 25-38. http://dx.doi.org/10.1016/j.prevetmed.2005.01.013

B, ROJO-BEZARES, B, SAENZ, Y POETA, et al. 2006. Assessment of antibiotic susceptibility within lactic acid bacteria strains isolated from wine. Int $\begin{array}{llll}J & \text { Food } & \text { Microbiol } & \text { 234-240. }\end{array}$ http://dx.doi.org/10.1016/j.ijfoodmicro.2006.06.007

BJORKROTH, K.J., SCHILLINGER, U., GEISEN, R., WEISS, N., HOSTE, B., HOLZAPFEL, W.H., KORKEALA, H.J., VANDAMME, P. 2002. Taxonomic study of Weissella confusa and description of Weissella cibaria sp. nov., detected in food and clinical samples. Int J Syst Evol Microbiol 52. 141-148.

BUJNAKOVA, D., STRAKOVA, E., KMET, V. 2014. In vitro evaluation of the safety and probiotic properties of Lactobacilli isolated from chicken and calves. Anaerobe 29, 118-127. http://dx.doi.org/10.1016/j.anaerobe.2013.10.009 
CAPCAROVÁ, M., WEIS, J., HRNČÁR, C., KOLESÁROVÁ, A., PETRUŠKA, P., KALAFOVÁ, A., PÁL, G., 2011. Effect of Probiotic Supplementation on Selected Indices of Energy Profile and Antioxidant Status of Chickens. $J$ Microbiol Biotech Food Sci 1 (2) 225-235.

CATALOLUK, O., GOGEBAKAN, B.. 2004. Presence of drug resistance in intestinal lactobacilli of dairy and human origin in Turkey. FEMS Microbiol Lett 236. 7-12. http://dx.doi.org/10.1111/j.1574-6968.2004.tb09620.x

CITAK, S., YÜCEL, N., ORHAN, S. 2004. Antibiotic resistance and incidence of Enterococcus species in Turkish white cheese. Int J Dairy Technol 57 (1). 27 32. http://dx.doi.org/10.1111/j.1471-0307.2004.00122.x

D'AIMMO, M.R., MODESTO, M., BIAVATI, B. 2007. Antibiotic resistance of lactic acid bacteria and Bifidobacterium spp. isolated from dairy and pharmaceutical products. Int $J$ Food Microbiol 115 (1). 3542.http://dx.doi.org/10.1016/j.ijfoodmicro.2006.10.003

DANIELSEN, M., WIND, A. 2003. Susceptibility of Lactobacillus spp. to antimicrobial agents. Int J Food Microbiol $82 . \quad 1-11$ http://dx.doi.org/10.1016/S0168-1605(02)00254-4

DANIELSEN, M., SIMPSON, P.J., O'CONNOR, O.B., ROSS, R.P., STANTON, C. 2007.Susceptibility of Pediococcus spp. to antimicrobial agents. $J$ Appl Micr 102, 384-389. http://dx.doi.org/10.1111/j.1365-2672.2006.03097.x DRAHOVSKÁ, H., SLOBODNÍKOVÁ, L., KOCÍNCOVÁ, D., SEMAN, M. KONCEKOVÁ, R., TRUPL, J., TURNA, J. 2004. Antibiotic resistance and virulence factors among clinical and food enterococci isolated in Slovakia. Folia Microbiol 49(6):763-8. http://dx.doi.org/10.1007/BF02931562

ELISHA, B.G., COURVALIN, P. 1995. Analysis of genes encoding dalanine:dalanine ligase-related enzymes in Leuconostoc mesenteroides and Lactobacillus spp. Gene 152, 79-83.http://dx.doi.org/ 10.1016/0378-1119(94)00692-L

EFSA 2008. Technical guidance Update of the criteria used in the assessment of bacterial resistance to antibiotics of human or veterinary importance Prepared by the Panel on Additives and Products or Substances used in Animal Feed. European Food Safety Authorization 732. 1-15.

EFSA 2004. EFSA Scientific Colloqium Summary Report. QPS: qualified presumption of safety of microorganisms in food and feed. European Food Safety Authority, Brussels, Belgium

FRANZ, C.M.A.P., MUSCHOLL-SILBERHORN, A.B., YOUSIF, N.M.K VANCANNEYT, M., SWINGS, J., HOLZAPFEL, W.F. 2001. Incidence of Virulence Factors and Antibiotic Resistance among Enterococci Isolated from Food. Appl Environ Micr 67 (9), 4385-4389. http://dx.doi.org/10.1128/AEM.67.9.4385-4389.2001

FLO' REZ, A.B., DELGADO, S., MAYO, B. 2005. Antimicrobial susceptibility of lactic acid bacteria isolated from a cheese environment. Can J Microbiol 51, 51-58. http://dx.doi.org/10.1139/w04-114

GEVERS, D., DANIELSON, M., HUYS, G., SWINGS, J. 2003. Molecular characterization of tet(M) genes in Lactobacillus isolates from different types of fermented dry sausage. Appl Environ Microbiol 69, 1270-1275. http://dx.doi.org/10.1128/AEM.69.2.1270-1275.2003

GEVERS, D., HUYS, G., DEVLIEGHERE, F., UYTTENDAELE, M. DEBEVERF, J., SWINGS, J. 2000. Isolation and identification of Tetracycline Resistant Lactic acid bacteria from pre-packed sliced meat products. Syst Appl Microbiol 23, 279-284. http://dx.doi.org/10.1016/S0723-2020(00)80015-6

GFELLER, K.Y., ROTH, M., MEILE, L., TEUBER, M. 2003. Sequence and genetic organization of the 19.3-kb erythromycin- and dalfopristin resistance plasmid pLME300 from Lactobacillus fermentum ROT1. Plasmid 50, 190-201. http://dx.doi.org/10.1016/j.plasmid.2003.08.001

HARLAN, N.P., KEMPKER, R.R., PAREKH, S.M., BURD, E.M., KUHAR, D.T. 2011. Weissella confusa bacteremia in a liver transplant patient with hepatic artery thrombosis. Transpl Infect Dis.13 (3) : 290-3. http://dx.doi.org/10.1111/j.1399-3062.2010.00579.x

HERRERO, M., MAYO, B., GANZALES, B., SUAREZ, J.E. 1996, Evaluation of technologically important traits in lactic acid bacteria isolated from spontaneous fermentations. $J$ Appl Bacteriol 81, 565-570. http://dx.doi.org/10.1111/j.1365-2672.1996.tb03548.x

HUMMEL, A.S., HERTEL, C., HOLZAPFEL, W.H., FRANZ, C.M.A.P. 2007. Antibiotic resistances of starter and probiotic strains of lactic acid bacteria. Appl Environ Microbiol 73, 730-739. http://dx.doi.org/10.1128/AEM.02105-06

HUYS, G., D'HAENE, K., COLLARD, J.M., SWINGS, J. 2004. Prevalance and molecular characterization of tetracycline resistance in Enterococcus isolates from food. Appl Environ Microbiol 70. 1555-1562. http://dx.doi.org/10.1128/AEM.70.3.1555-1562.2004

ISO 10932:2010 (Milk and milk products - Determination of the minimal inhibitory concentration (MIC) of antibiotics applicable to bifidobacteria and non-enterococcal lactic acid bacteria (LAB).

JOHNSTON, L.M., JAYKUS L.A., 2004. Antimicrobial Resistance of Enterococcus Species Isolated from Produce. Appl Environ Micr 70 (5). 3133 3137. http://dx.doi.org/10.1128/AEM.70.5.3133-3137.2004

KLARE, I., KONSTABEL, C., MULLER-BERTLING, S., REISSBRODT, R., HUYS, G., VANCANNEYT, M., SWINGS, J., GOOSSENS, H.,WITTE, W
2005. Evaluation of new broth media for microdilution antibiotic susceptibility testing of Lactobacilli, Pediococci, Lactococci, and Bifidobacteria. Appl Environ Microbiol 71. 8982-8986. http://dx.doi.org/10.1128/AEM.71.12.8982$\underline{8986.2005}$

KLEIN, G., HALLMANN, C., CASAS, I.A., ABAD, J., LOUWERS, J., REUTER, G. 2000. Exclusion of vanA, vanB and vanC type glycopeptide resistance in strains of Lactobacillus reuteri and Lactobacillus rhamnosus used as probiotics by polymerase chain reaction and hybridization methods. J Appl Microbiol 89, 815-824. http://dx.doi.org/10.1046/j.1365-2672.2000.01187.x

KLEINSCHMIDT, J., SOEDING, B., TEUBER, M., NEVE, H. 1993 Evaluation of horizontal and vertical gene transfer and stability of heterologous DNA in Streptococcus thermophilus isolated from yogurt and yogurt starter cultures. Syst Appl Microbiol 16. 287-295. http://dx.doi.org/10.1016/S0723-2020(11)80482-0 KUMAR, A., AUGUSTINE, D., SUDHINDRAN, S., KURİAN, A.M., DINESH, K.R., KARIM, S., PHILIP, R. 2011. Weissella confusa: a rare cause of vancomycin-resistant Gram-positive bacteraemia. J Med Microbiol 60, 1539-41. http://dx.doi.org/10.1099/jmm.0.027169-0

LAHTINEN, S., OUWEHAND, A.C., SALMINEN, S., WRIGGHT, A.V. 2011 Lactic acid bacteria, Microbiological and Functional Aspects, Fourth Edition, CRC Press, USA, 798 p. ISBN 978-1-4398-3677-4.

LEROY, F., DE VUYST, L. 2004. Lactic acid bacteria as functional starter cultures for the food fermentation industry. Trends Food Sci Technol 15. 67-78. http://dx.doi.org/10.1016/j.tifs.2003.09.004

MATHUR, S., SINGH, R. 2005. Antibiotic resistance in food lactic acid bacteria. $\begin{array}{lllll}\text { Int } J & \text { Food } & \text { Microbiol } & 105 . & \end{array}$ http://dx.doi.org/10.1016/j.ijfoodmicro.2005.03.008

OUOBA, LII., LEI, V., JENSEN, L.B. 2008. Resistance of potential probiotic lactic acid bacteria and bifidobacteria of African and European origin to antimicrobials: determination and transferability of the resistance genes to other $\begin{array}{lllll}\text { bacteria. Int } J \text { Food Microbiol 121. 217-224 } & \end{array}$ http://dx.doi.org/10.1016/j.ijfoodmicro.2007.11.018

RONIMUS, R.S., PARKER, LE., MORGAN, H.W. 1997. The utilization of RAPD-PCR for identifying thermophilic and mesophilic Bacillus species. FEMS Microbiol Lett 147. 75-79. http://dx.doi.org/10.1016/S0378-1097(96)00507-1

SABIR, F., BEYATLI, Y., COKMUS, C., ONAL-DARILMAZ, D. 2010. Assessment of Potential Probiotic Properties of Lactobacillus spp., Lactococcus spp., and Pediococcus spp. strains Isolated from Kefir. J Food Sci 75 (9). 568573. http://dx.doi.org/10.1111/j.1750-3841.2010.01855.x

SCHLEIFER, K.H., LUDWIG, W., 1995. Phylogenetic relationships of lactic acid bacteria. In: Wood, BJB., Holzapfel, wh (Eds). The lactic acid bacteria. Vol.2: The genera of lactic acid bacteria. Blackie Academic and Professional, Glasgow, pp. 7-18. http://dx.doi.org/10.1007/978-1-4615-5817-0_2

SHARMA, N., GARCHA, S., SINGH, S. 2013. Potential of Lactococcus lactis subsp. lactis MTCC 3041 as a biopreservative. J Microbiol Biotech Food Sci, 3 (2) $168-171$.

SIMPSON, W.J., TAGUCHI, H.1995. The genus Pediococcus, with notes on the genera Tetratogenococcus and Aerococcus. In: The Genera of Lactic Acid Bacteria 125-172. Blackie Academic \& Professional, London. ISBN 075-140215-X.

SUTCLIFFE, J., GREBE, T., TAIT-KAMRADT, A., WONDRACK, L. 1996 Detection of erythromycin-resistant determinants by PCR. Antimicrob Agents Chemotherapy 40 (11), 2562-2566.

SWENSON, J.M., FACKLAM, R.R., THORNSBERRY, C. 1990. Antimicrobial susceptibility of vancomycin-resistant Leuconostoc, Pediococcus, and Lactobacillus species. Antimicrob Agents Chemotherapy 34, 543-549. http://dx.doi.org/10.1128/AAC.34.4.543

TEMMERMAN, R., POT, R., HUYS, B., SWINGS, J. 2003. Identification and antibiotic susceptibility of bacterial isolates from probiotic products. Int J Food Microbiol 81 (1), 1-10. http://dx.doi.org/10.1016/S0168-1605(02)00162-9

THUMU, S.C.R., HALAMI, P.M. 2012. Acquired resistance to MacrolideLincosamide-Streptogramin Antibiotics in Lactic Acid Bacteria of Food Origin Indian J Microbiol 52 (4), 530-537. http://dx.doi.org/10.1007/s12088-012-0296-5 VAY, C., CITTADINI, R., BARBERIS, C., HERNA'N RODRI'GUEZ, C., MARTI'NEZ, H.P., GENERO, F., FAMIGLIETTI, A. 2007. Antimicrobial susceptibility of non-enterococcal intrinsic glycopeptide-resistant Gram-positive organisms, Diagnostic Microbiology and Infectious Disease 57, 183-188. http://dx.doi.org/10.1016/j.diagmicrobio.2006.08.014

VALENZUELA, A.V., OMAR, N.B., ABRIOUEL, H., LOPEZ, R.L.,ORTEGA, E., CANAMERO, M.M., GALVEZ, A. 2008. Risk factors in enterococci isolated from foods in Morocco: Determination of antimicrobial resistance and incidence of virulence traits. Food Chem Toxicol46 (2008) 2648-2652. http://dx.doi.org/10.1016/j.fct.2008.04.021

WALTER, J., HERTEL, C., TANNOCK, G.W., LIS, C.M., MUNRO, K., HAMMES, W.P. 2001 Detection of Lactobacillus, Pediococcus, Leuconostoc and Weissella species in human feces by using group-specific PCR primers and denaturing gradient gel electrophoresis. Appl Environ Microbiol 67, 2578-2585. http://dx.doi.org/10.1128/AEM.67.6.2578-2585.2001 
WERNER, G., WILLEMS, R.J., HILDEBRANDT, B., KLARE, I., WITTE, W 2003. Influence of transferable genetic determinants on the outcome of typing methods commonly used for Enterococcus faecium. J Clin Microbiol 41. 14991506. http://dx.doi.org/10.1128/JCM.41.4.1499-1506.2003

ZHOU, J.S., PILLIDGE, C.J., GOPAL, P.K., GILL, H.S. 2005. Antibiotic susceptibility profiles of new probiotic Lactobacillus and Bifidobacterium strains.

http://dx.doi.org/10.1016/j.ijfoodmicro.2004.05.011 